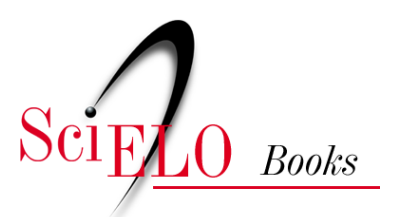

\title{
19 Tribo Anthemideae Cass.
}

\author{
Angelo Alberto Schneider
}

SHNEIDER, A.A. Tribo Anthemideae Cass. In: ROQUE, N. TELES, A.M., and NAKAJIMA, J.N., comp. A família Asteraceae no Brasil: classificação e diversidade [online]. Salvador: EDUFBA, 2017, pp. 149151. ISBN: 978-85-232-1999-4. https://doi.org/10.7476/9788523219994.0021.

All the contents of this work, except where otherwise noted, is licensed under a Creative Commons Attribution 4.0 International license.

Todo o conteúdo deste trabalho, exceto quando houver ressalva, é publicado sob a licença Creative Commons Atribição $\underline{4.0}$.

Todo el contenido de esta obra, excepto donde se indique lo contrario, está bajo licencia de la licencia Creative Commons Reconocimento 4.0. 


\section{TRIBO ANTHEMIDEAE CASS.}

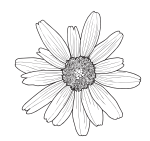

Angelo Alberto Schneider

Anthemideae está representada por 111 gêneros e cerca de 1.800 espécies (OBERPRIELER; VOGT; WATSON, 2007), sendo que a maior concentração de seus táxons está na Ásia Central, Mediterrâneo e sul da África.

A tribo caracteriza-se por apresentar lâmina foliar com margem 1-3-dividida, palmada ou pinatífida, sendo os lóbulos externos usualmente lineares a filiformes, algumas vezes denteada ou ainda inteira, brácteas involucrais em 2-7 séries desiguais, pápus nulo ou formando por escamas, raramente cerdas.

\section{Descrição}

Ervas anuais, bianuais ou perenes, subarbustos ou arbustos; plantas com tricomas, raro ausentes, geralmente tricomas glandulares bisseriados em formato de " $\mathrm{T}$ " ou estrelados. Folhas comumente alternas, denteadas, serradas, lobadas, pinatífidas ou pinatissectas, raro inteiras. Capitulescência corimbiforme, paniculiforme, racemiforme ou glomeruliforme, laxa a congesta, ou capítulos solitários. Capítulos frequentemente pedunculados, radiados ou disciformes, heterógamos ou discoides homógamos; invólucros hemisféricos, obcônicos, cilíndricos ou urceolados; brácteas involucrais 2-7-seriadas, imbricadas, às vezes com canais de resina, quase sempre com margens e ápices escariosos; receptáculo plano, hemisférico, cônico, glabro ou piloso, paleáceo ou epaleáceo, páleas planas ou naviculares, persistentes ou não. Flores do raio pistiladas férteis, estéreis ou ainda neutras, limbo 
branco, amarelo, rosado ou avermelhado; flores mais externas do disco em 1 ou muitas séries, pistiladas, normalmente férteis; corola tubulosa e com 0-5 lobos apicais, amarelas, raro ausentes; flores centrais do disco bissexuais ou funcionalmente masculinas, corola tubular, infundibuliforme, actinomorfa, 3-6 lobos, amarela, raramente alva ou avermelhada; anteras com apêndice apical normalmente ovado, triangular, raro caudadas, colar da antera espesso, cilíndrico; estilete com base bulbosa ou lisa, geralmente inserida no estilopódio (nectário); ramos do estilete lineares, ápice truncado e penicilado. Cipsela obovoide, obcônica ou cilíndrica, geralmente costada, algumas aladas; pápus ausente ou coroniforme (escamas fundidas na base), ou ainda cerdas escamiformes.

A tribo Anthemideae está representada no Brasil por 10 gêneros, sendo que 9 são exóticos e apenas 1 é nativo, Soliva Ruiz \& Pav. A maioria refere-se a plantas exóticas e conhecidas por serem plantas aromáticas, com valor farmacêutico (Achillea L., Artemisia L., Matricaria L. e Tanacetum L.), ornamental (Chrysanthemum L. e Leucanthemum Mill.) ou ainda plantas subespontâneas (Anthemis L., Coleostephus Cass., Cotula L. e Soliva Ruiz \& Pav.). Representantes de Anthemideae são encontrados na Figura 16A-F.

\section{Chave de identificação para os gêneros de Anthemideae no Brasil}

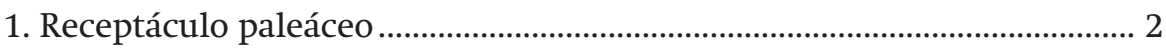

1'. Receptáculo epaleáceo .................................................................................... 4

2. Páleas restritas às flores marginais .............................................. Tanacetum

2'. Páleas em todo receptáculo ........................................................................... 3

3. Capitulescência corimbiforme, congesta; invólucro cilíndrico ......Achillea

3'. Capitulescência corimbiforme, laxa ou capítulos solitários; invólucro hemisférico Anthemis

4. Capítulos radiados; flores marginais com corola ligulada, conspícua (Figura 13L) 5

4'. Capítulos discoides ou disciformes; flores marginais com corola 3-denteada, filiforme ou ausentes 8 
5. Plantas anuais; de uso medicinal ou infestantes........................................... 6

5'. Plantas perenes; de uso ornamental .............................................................. 7

6. Capítulos com lígulas amarelas; cipselas 10-costadas............. Coleostephus

6'. Capítulos com lígulas brancas; cipselas 5-costadas.................... Matricaria

7. Folhas inteiras, dentado-serreadas ou parcialmente lobadas; cipselas 10-costadas, costas projetadas no ápice da cipsela em forma de anel

Leucanthemum

7'. Folhas pinatissectas, lobadas; cipselas 5-8-costadas, costas não projetadas no ápice da cipsela

Chrysanthemum

8. Capitulescência paniculiforme

Artemisia

8'. Capítulos solitário. 9

9. Capítulos sésseis; estiletes das flores pistiladas persistentes e espinescentes no fruto Soliva

9'. Capítulos pedunculados; estiletes das flores pistiladas não persistentes no fruto Cotula

\section{Literatura recomendada}

BARKLEY, T. M.; BROUILLET, L.; STROTHER, J. L. Anthemideae. In: FLORA OF NORTH AMERICA EDITORIAL COMMITTEE. Flora of North America. Oxford: Oxford University Press, 2006. v. 19, p. 485-486.

CABRERA, A. L. Compositae. In: BURKART, A. (Org.). Flora ilustrada de entre rios (Argentina). Buenos Aires: Colecion Cientifica del INTA, 1974.

p. 106-554.

LIN, Y. R. et al. Anthemideae. In: WU, Z. Y.; RAVEN, P. H.; HONG, D. Y. (Ed.). Flora of China (Asteraceae). St. Louis: Science Press (Beijing) \& Missouri Botanical Garden Press, 2011. v. 20-21, p. 653-773.

OBERPRIELER, C; R. VOGT, C. O.; WATSON, L. E. Tribe Anthemideae. In: KADEREIT, J. W.; JEFFREY, C. (Ed.). The Families and Genera of Vascular Plants: v. VIII: Flowering Plants: Eudicots - Asterales. Berlin: Springer-Verlag, 2007. p. 342-374. 